\title{
Pengaruh Jarak Awalan dalam Lompat Jauh terhadap Hasil Lompatan pada Siswa Putra Kelas IV
}

\author{
Sandi Achmad Pratama \\ Dosen Program studi Jasmasni Kesehatan dan Rekreasi, STKIP Yapis Dompu \\ E-mail: sandiahmad250591@gmail.com
}

Article History: Received: 2021-07-22 || Revised: 2021-07-28 || Published: 2021-08-26

Sejarah Artikel : Diterima: 2021-07-22 || Direvisi: 2021-07-28 || Dipublikasi: 2021-08-26

\begin{abstract}
The goal to be achieved in this study is to find out how far the distance between the Prefix Distance and the Jump on the results of the jump in the male students of Class IV SDN 1 Dompu in the 2019/2020 school year, its uses: (1) Theoretical uses, namely for information obtained in research This is beneficial for scientists in the field of sports to be able to develop concepts in order to improve sports performance, especially in the Long Jump sport. (2) Practical Use The results of this study are expected to be used as a theoretical consideration for players in jumping, in sports and can make a valuable contribution to society, especially sports coaches in an effort to help and develop long jump athletes. The population in this study was the fourth grade male students of SDN 1 Dompu for the 2019/2020 school year, totaling 12 students. The instrument used to obtain the data in this study is a test instrument, while the test used in this study is to provide an action test. This action test is in the form of a long jump test with a starting distance of $20 \mathrm{~m}$ and $30 \mathrm{~m}$. The method used is to obtain data in this study, namely: Methods of documentation and test actions. Meanwhile, the data analysis used statistical analysis with the t-test formula. Where the results of $t$ arithmetic are greater than $\mathrm{t}$ tables, namely $3.539>2.201$ at a significance level of $5 \%$ with $\mathrm{db}(\mathrm{N}-1)=11$, it can be concluded that in this study "There is an Effect of Distance Prefix with Jumping on Jump Results in Male Students in Class IVA SDN 1 Dompu for the 2019/2020 school year.
\end{abstract}

Keywords: Distance, Prefix, Jump Result.

\begin{abstract}
Abstrak
Tujuan yang ingin dicapai dalam penelitian ini adalah untuk Mengetahui seberapa jauh jarak Pengaruh Jarak Awalan Dengan Lompat Terhadap Hasil Lompatan Pada Siswa Putra Kelas IVA SDN 1 Dompu tahun Pembelajaran2019/2020, kegunaannya : (1) Kegunaan teoritis yaitu untuk, informasi yang diperoleh dalam penelitian ini bermanfaat bagi ilmuan di bidang olahraga untuk dapat mengembangkan konsep dalam rangka meningkatkan prestasi olahraga terutama dalam cabang olaharaga Lompat Jauh . (2) Kegunaan Praktis Hasil penelitian ini diharapkan dapat dijadikan salah satu pertimbangan teoritis bagi para pemain dalam melakukan lompatan, dalam berolahraga dan dapat memberi sumbangan yang berharga bagi masyarakat, khususnya para pembina olahraga dalam upaya membantu dan membina para atlet lompat jauh. Populasi dalam penelitian ini adalah Siswa Putra Kelas IV SDN 1 Dompu tahun Pembelajaran2019/2020 yang berjumlah 12 orang siswa. Instrument yang digunakan untuk memperoleh data-data dalam penelitian ini adalah instrument tes, adapun tes yang digunakan dalam penelitian ini adalah dengan memberikan test perbuatan, pemberian test perbuatan ini berupa test lompat jauh dengan jarak awalan $20 \mathrm{~m}$ dan $30 \mathrm{~m}$. Metode yang digunakan adalah untuk memperoleh data dalam penelitian ini yaitu: Metode dokumentasi dan tes perbuatan. Sedangkan analisa data menggunakan analisis stastistik dengan rumus t-test, dimana hasil $t$ hitung lebih besar daripada $t$ tabel yaitu 3,539 > 2,201 pada taraf signifikansi 5\% dengan db (N-1)=11 Maka dapat disimpulkan bahwa dalam penelitian ini “Ada Pengaruh Jarak Awalan Dengan Lompat Terhadap Hasil Lompatan Pada Siswa Putra Kelas IVA SDN 1 Dompu tahun Pembelajaran2019/2020.
\end{abstract}

Kata kunci: Jarak, Awalan, Hasil Lompatan.

\section{PENDAHULUAN}

Atletik merupakan salah satu dari cabang olahraga yang mudah dilakukan, namun begitu cabang olahraga ini kurang diminati olah masyarakat, sebab biasanya masyarakat cenderung menyukai jenis-jenis olahraga yang mengandung unsur permainan, Atletik merupakan induk dari segala cabang olahraga salah satunya yaitu nomor lompat jauh.Lompat jauh adalah suatu cabang olahraga 
atletik yang masuk kurikulum sekolah. Hal ini dimaksudkan supaya siswa bisa mengenal cabang olahraga ini sejak usia dini/awal usia sekolah, karena sekolah atau lembaga pendidikan merupakan salah satu tempat yang sangat efektif untuk menyalurkan minat serta bakat siswa. Dengan adanya minat atau kemampuan yang keras untuk berlatih serta didukung oleh bakat dan kemampuan yang bagus pada siswa diharapkan para siswa bisa mencapai hasil yang maksimal baik ditingkat regional, nasional bahkan internasional, terdapat hubungan yang sangat erat antara karaktiristik gerak cabang olahraga dengan komponen-komponen fisik yang mendukung.

Pencapaian prestasi seorang atlet ini yang mendorong peneliti untuk melaksanakan penelitian yang bertujuan untuk meningkatkan hasil lompatan dalam lompat jauh dengan memberikan jarak awalan yang berbeda, pelaksanaan penelitian ini dilakukan mengingat bahwa salah satu cabang olahraga yang mendapat prioritas utama di Provinsi Nusa Tenggara Barat adalah cabang olahraga atletik, dimana lewat cabang ini atlet-atlet sudah banyak yang berprestasi mendapat medali pada event-event olahraga baik tingkat regional, nasional bahkan internasional. Dari uraian di atas maka peneliti ingin mencoba meneliti secara ilmiah mengenai pengaruh jarak awalan dalam lompat jauh terhadap hasil lompatan pada siswa putra kelas IVA SDN 1 Dompu tahun Pembelajaran2019/2020. Berdasarkan uraian pada latar belakang masalah di atas maka peneliti dapat merumuskan masalah sebagai berikut : "Apakah ada pengaruh jarak awalan dalam lompat jauh terhadap hasil lompatan pada siswa putra kelas IVA SDN 1 Dompu tahun Pembelajaran2019/2020?". Untuk memberikan penjelasan mengenai variabel-variabel yang berhubungan dengan pelaksanaan penelitian ini, maka perlu diberikan batasan diantaranya: 1) Pengaruh Dalam kamus bahasa Indonesia kata pengaruh berarti daya atau efek yang ada atau timbul oleh seseorang (Poerwadarminta, 1976: 28), jadi pengaruh menurut peneliti adalah daya atau efek yang ditimbulkan oleh seseorang siswa putra kelas IVA SDN 1 Dompu dalam melakukan lompatan. 2) Jarak 20 Meter Dan 30 Meter adalah jarak yang harus dilalui untuk mengambil awalan guna melakukan lompatan 3) Hasil lompatan adalah skor maksimal yang diperoleh testee (subyek penelitian) dari test lompat jauh yang dilakukan sebanyak tiga kali lompatan yang diukur dengan satuan meter, dalam hal ini gaya yang digunakan adalah khusus gaya jongkok.

Berikut disampaikan beberapa teori yang dapat mendukung kebenaran penelitian ini:

1. Jarak Awalan

Awalan dengan lompatan menuntut kecepatan yang tinggi dan konstan sampai kaki tumpu dapat menjejakkan kaki pada papan tolakan dengan cepat, lompatan yang baik adalah tidak ada perubahan langkah menjelang papan tolakan, hal ini dimungkinkan pada jarak yang tidak terlalu jauh sehingga pelompat mencapai kecepatan maksimal. Dengan kecepatan pada awalan inilah mampu membuat dorongan ke depan, dengan menggunakan awalan bertujuan untuk mendapatkan kecepatan yang maksimal sebelum mencapai balok tumpuan dengan melakukan lari cepat untuk mendapatkan dorongan ke depan yang lebih banyak saat melompat dan melayang di udara.

\section{Hasil Lompatan}

Hasil lompatan adalah hasil maksimal yang diperoleh oleh seorang siswa setelah melakukan lompatan dimana Tujuan lompatan ini adalah melompat sejauh-jauhnya dengan memindahkan seluruh tubuh dari titik tertentu ke titik lainnya dengan cara berlari secepat-cepatnya, kemudian menolak melayang di udara dan mendarat.

\section{Teknik Lompatan}

Selain memiliki kecepatan, kekuatan, kelenturan, daya tahan, dan reaksi yang baik atlet juga harus menguasai teknik-teknik dalam melompat, adapun teknik-teknik yang dimaksud yaitu : A) Teknik Awalan awalan pada lompatan berfungsi untuk mendapatkan kecepatan yang setinggi-tingginya sebelum mencapai tolakan atau balok tumpuan. Cara melakukan awalan pada lompatan sebagai berikut: (1) Lari awal bergantung pada masing-masing pelompat. (2) Perubahan kecepatan lari awalan sedikit demi sedikit sebelum bertumpu atau bertolak (3) Pinggang diturunkan pada akhir awalan, B) Teknik Bertumpu Tumpuan atau tolakan kaki harus kuat agar bisa mencapai lompatan tinggi yang cukup tampak kehilangan kecepatan. Cara melakukan tumpuan atau tolakan antara lain sebagai berikut: (1) Ayunan paha kaki secara cepat ke posisi harizontal dan dipertahankan, (2) Luruskan sendi kaki, lutut dan pinggang saat 
melakukan tolakan. (3) Bertolak ke depan atas, (4) Sudut tolakan sebesar 45 derajat. C) Teknik Melayang di Udara Sikap badan melayang di udara adalah setelah gerakan kaki tolak menolak atau menumpu pada balok tumpuan, badan terangkat cepat sehingga melayang ke udara bersamaan dengan ayunan kedua lengan ke depan atas, tinggi dan jauhnya hasil lompatan sangat bergantung pada besarnya kekuatan tolakan pada saat menolak dan kecepatan pelompat dalam meluruskan kaki selurus-lurusnya, D) Tehnik mendarat :Mendarat harus dilakukan sedemikian rupa sehingga kaki diayunkan ke depan menyebabkan seorang pelompat mendarat dengan pantatnya, karena bila terjadi demikian akan sangat merugikan. Cara melakukan pendaratan sebagai berikut: 1) Tarikan lengan dan tubuh ke bawah, setelah itu tariklah kaki mendekati badan, 2) Luruskan kaki dan tekuk sedikit sebelum menyentuh tanah dan Bila kedua kaki telah mendarat di bak pasir, maka duduklah di kedua kaki.

Dalam penelitian ini ditentukan Dugaan Sementara, atau yang biasa disebut dengan Hipotesis, Menurut Arikunto (2006:64) hipotesis adalah suatu jawaban yang sifatnya sementara terhadap permasalahan penelitian sampai terbukti melalui data yang terkumpul, pendapat ahli lain mengemukakan bahwa hipotesis adalah jawaban sementara terhadap masalah penelitian yang secara teoritis dianggap paling mungkin dan paling tinggi tingkat kebenarannya (Sutaryono, dkk, 2003; 13), dengan demikian hipotesis merupakan jawaban sementara yang sifatnya sementara yang kebenarannya membutuhkan pembuktian, ada 2 macam hipotesis: 1 . Hipotesis Nihil (Ho) yaitu hipotesis yang menyatakan tidak ada hubungan antara variabel satu dengan variabel lainnya, 2. Hipotesis Alternatif (Ha) yaitu hipotesis yang menyatakan ada hubungan atau adanya perbedaan antara dua kelompok, berdasarkan uraian pada latar belakang masalah serta menurut pendapat para ahli, maka rumusan masalah hipotesis penelitian yang diajukan adalah sebagai berikut "Ada pengaruh jarak awalan dengan lompat terhadap hasil lompatan pada siswa putra kelas IVA SDN 1 Dompu tahun Pembelajaran2019/2020.

\section{METODE PENELITIAN}

Jenis penelitian yang digunakan dalam penelitian ini yaitu penelitian kuantitatif, Populasi yang digunakan dalam penelitian ini yaitu: siswa putra kelas IVA SDN 1 Dompu tahun Pembelajaran2019/2020, yang berjumlah 12 orang, dengan sampel sebanyak 12 orang siswa, Untuk memperoleh data yang diperlukan dalam penelitian, maka penelitian menggunakan dua macam pengumpulan data yaitu (A) Metode Dokumentasi: adalah suatu cara untuk memperoleh data dengan jalan mengumpulkan dokumen serta mengadakan pencatatan yang sistematis (Yosda, 1993 : 77), sedangkan ahli lain mengatakan bahwa "Metode dokumentasi adalah suatu cara untuk mencari data atau hal-hal yang berupa catatan transkrip" (Margono, 1997 : 56). Metode ini dipergunakan untuk memperoleh data-data mengenai jumlah nama-nama siswa putra kelas IVA SDN 1 Dompu tahun Pembelajaran2019/2020, (2)Tes Perbuatan: Test perbuatan alat pengumpulan data yang berbentuk suruhan- suruhan yang harus dilaksanakan oleh subyek penelitian (Kusma, 1998 : 28), ahli lain mengatakan bahwa "test perbuatan adalah suatu cara untuk mengadakan penelitian terhadap suatu subyek atau obyek-obyek tertentu untuk mendapatkan data secara cepat dan tepat (Arikunto, 2006: 44 ).

\section{HASIL DAN PEMBAHASAN}

Data-data yang diperoleh dalam pelaksanaan penelitian ini adalah data-data mengenai identitas siswa SDN 1 Dompu tahun Pembelajaran2019/2020 dan data hasil tes lompat jauh pada jarak awalan 20 meter dan 30 meter, data-data tentang identitas pada siswa SDN 1 Dompu tahun Pembelajaran2019/2020 diperoleh pada awal pelaksanaan penelitian yaitu pada saat penentuan sampel, sebagai subyek yang akan digunakan dalam penelitian ini, selanjutnya untuk mengetahui hasil lompat jauh pada siswa pengaruh jarak awalan $20 \mathrm{~m}$ dan $30 \mathrm{~m}$ dengan lompat terhadap hasil lompatan pada SDN 1 Dompu tahun Pembelajaran2019/2020 sebagai subyek penelitian adalah setelah melaksanakan tes perbuatan, dalam hal ini melakukan tes lompat jauh dengan jarak 20 meter dan 30 meter pada masing-masing subyek penelitian, analisa data tentang pengaruh jarak awalan $20 \mathrm{~m}$ dan $30 \mathrm{~m}$ dengan lompat terhadap hasil lompatan pada siswa putra kelas IVA SDN 1 Dompu tahun Pembelajaran2019/2020. Merumuskan Hipotesis (Ho) Untuk keperluan perhitungan analisis statistik, maka hipotesis alternatif $(\mathrm{Ha})$ yang diajukan berbunyi "Ada pengaruh jarak 
awalan $20 \mathrm{~m}$ dan $30 \mathrm{~m}$ dengan lompat terhadap hasil lompatan pada siswa putra kelas IVA SDN 1 Dompu tahun Pembelajaran2019/2020 maka harus dirubah dahulu menadi hipotesis nihil (Ho) yang berbunyi tidak ada pengaruh jarak awalan $20 \mathrm{~m}$ dan $30 \mathrm{~m}$ dengan lompat terhadap hasil lompatan pada SDN 1 Dompu tahun Pembelajaran2019/2020, Menguji nilai " $t$ " Dari hasil penelitian ternyata nilai t-test yang diperoleh dari penelitian ini adalah 3,539 sedangkan nilai t-test dalam tabel dengan tarif signifikan 5\% serta derajat kebebasan $(\mathrm{db}) \mathrm{N}-1(12-1=11)$ adalah 2,201 kenyataan ini menunjukkan bahwa nilai t-hitung yang diperoleh dalam penelitian ini adalah lebih besar dari nilai t-test tabel. Menarik kesimpulan Dari hasil pengujian nilai " $t$ " di atas, dimana $t$ hitung adalah 3,539 lebih besar dari nilai t-tabel sebesar 2,201 dengan taraf signifikan 5\%, maka dapat dikemukakan bahwa hipotesis nol (Ho) ditolak dan hipotesis alternatif (Ha) diterima, maka kesimpulan analisis dalam penelitian ini adalah sebagai berikut : "Ada pengaruh jarak awalan dalam lompat jauh terhadap hasil lompatan pada siswa putra kelas IVA SDN 1 Dompu tahun Pembelajaran2019/2020. Berdasarkan hasil dari penelitian ini, ada kecenderungan semakin jauh jarak awalan yang dilakukan dalam lompat jauh maka semakin jauh hasil lompatan yang dihasilkan, hal ini dapat dilihat dari hasil penelitian yaitu $M_{I}>M_{I I}=427,41>274,41$, yang berarti angka rata-rata hasil lompatan dengan jarak awalan 30 meter lebih besar daripada angka rata-rata hasil lompatan dengan jarak awalan 20 meter. Dengan demikian di samping faktor awalan tadi masih banyak faktor lain yang dapat mempengaruhi hasil lompatan dalam lompat jauh tersebut diantaranya faktor latihan, kekuatan, stamina, daya ledak dll, hal ini didukung pula oleh pendapat seorang ahli yang mengemukakan bahwa latihan merupakan salah satu penentu dalam pencapaian prestasi yang maksimal (Soeharno Hp, 1985 : 8), sementara itu Engkos Kosasih (1990 : 7) mengemukakan bahwa seseorang yang sering melakukan latihan jangkauannya akan lebih baik dibandingkan dengan seseorang yang tidak pernah melakukan latihan, etapi dalam hal ini peneliti hanya meneliti sejauh mana jarak awalan dapat mempengaruhi hasil lompatan dalam lompat jauh.

\section{SIMPULAN DAN SARAN}

Berdasarkan penelitian yang telah dilakukan, dapat disimpulkan bahwa terdapat kecenderungan semakin jauh jarak awalan yang dilakukan dalam lompat jauh maka semakin jauh hasil lompatan yang dihasilkan, hal ini dapat dilihat dari hasil penelitian yaitu $M_{I}>M_{I I}=427,41>274,41$, yang berarti angka rata-rata hasil lompatan dengan jarak awalan 30 meter lebih besar dari pada angka rata-rata hasil lompatan dengan jarak awalan 20 meter, maka kesimpulan dalam penelitian ini adalah "Ada pengaruh jarak awalan dalam lompat jauh terhadap hasil lompatan pada siswa putra kelas IVA SDN 1 Dompu.

\section{DAFTAR RUJUKAN}

Agus Wijaya, 2010. Pengaruh jarak awalan 20 meter dengan 30 meter dalam lompat jauh terhadap hasil lompatan. FPOK IKIP Mataram

Djumidar, 2005. Dasar- Dasar Atletik. Jakarta, Universitas Terbuka. Ida Bagus Netra. 1974. Statistik Infrensial. Usaha Nsional Surabaya.

Enung Nurhasanah. (2021). Pengembangan Multimedia Pembelajaran Sejarah Perkembangan Islam Berbasis Macromedia Flash untuk Meningkatkan Hasil Belajar Mahasiswa. Ainara Journal Uurnal Penelitian Dan PKM Bidang Ilmu Pendidikan),2(3), 148-153. Retrieved from http://journal.ainarapress.org/index.php/ainj/article/view/69

Indra Kusuma, 2002. Menyusun Soal-Soal Tes. Lembaga Pendidikan IKIP Malang Margono, 1997. Metodologi Penelitian. Rineka Cipta, Jakarta.

Masruri, 2010. Pengaruh jarak awalan 20 meter dengan 40 meter dalam lompat jauh terhadap hasil lompatan. FPOK IKIP Mataram.

Poerwadarminta, 1976. Kamus Umum Bahasa Indonesia. Balai Pustaka, Jakarta.

Sopian Hadi 2009. Pengaruh lari sprint 50 meter terhadap lompat jauh, FPOK IKIP Mataram. 
Suharsimi, Arikunto, 2006. Prosedur penelitian, Bina Aksara Jakarta. Sutaryono, 2003. Pedoman Penulisan Skripsi. IKIP Mataram

Sutrisno Hadi, 1989. Metodologi Penelitian. Audi Offset, Yogyakarta. Syarifuddin, 1985. Pendidikan Jasmani. PT. Gramedia Widiasarana, Jakarta.

Tim, 2011. Pedoman Pembimbingan dan Penyusunan Karya Ilmiah, IKIP Mataram. Yousda, 1993. Statistik Pendidikan. Jakarta, Bina Aksara 